\title{
MATERIALS AND CONSTRUCTION TECHNIQUES OF TRADITIONAL HOUSES IN NOVI PAZAR, SERBIA
}

\author{
SAMRA UGLJANIN \& AYNUR CIFTCI \\ Faculty of Architecture, Y1ldız Technical University, Turkey
}

\begin{abstract}
Novi Pazar is one of the historic Ottoman settlements established in 1461 in the south-western part of Serbia. Due to its location on the crossroad of the big caravanserai road, which led from Dubrovnik to Istanbul, Novi Pazar played a great part in the economic development of the Balkans. The traditional texture of the town contains monumental buildings as well as houses that carry traces of Ottoman period architecture. The features of civil architecture in Novi Pazar, which is continuously being damaged, have not been subject to detailed documentation work and conservation studies up to now. It is observed that Novi Pazar houses that date back to the early years of the 19th century have several conservation problems, such as inappropriate interventions of users, climate circumstances and abandonment as a result of downturn of the economic situation. This study, as a part of a Master's thesis, consists of the documentation of more than 80 timber houses in use, and 18 of them documented in detail by means of onsite observations, survey drawings, photos and interviews with the local masters. The architectural morphology, timber framing and masonry walls techniques, floors, ceilings, roofs, mortars, plasters and indoor architectural elements were written by analyzing 18 traditional houses in detail.
\end{abstract}

Keywords: traditional houses, Novi Pazar, conservation, Ottoman period, timber structure.

\section{INTRODUCTION}

Novi Pazar is an historic Ottoman settlement established in 1461 in south-western part of Serbia and is on the crossroad of big caravanserai road which led from Dubrovnik to Istanbul. It has taken great part in economic development of Balkans during Ottoman era [1].

Architectural tissue of Novi Pazar consists of monuments that date back to the 16th century such as 17 mosques, 1 public bath ("hamam") and 1 khan as well as nearly 200 civil houses that carry traces of Ottoman period architecture and date back from early years of the 19th to the beginning of the 20th century [2].

Traditional houses are mostly located in historic district of old bazaar and on the right side of Raška River [3] (Fig. 1). It is a fact that detailed research about construction techniques and used materials has not been done, and besides that, civil architecture in Novi Pazar is continuously being damaged. That is the main reason why this topic was chosen for a master thesis.

Traditional houses in Novi Pazar were carrying some characteristics of traditional Ottoman houses but also have some specific architectural features due to the geographic, climate and cultural conditions and effects so they form a different type of houses as explained in the text below (Fig. 2).

\section{RESEARCH METHODOLOGY}

The research was started by general observation from outside of old districts as to document the remains of traditional civil architecture as a first step. Then, it was followed by, visiting Museum Ras of Novi Pazar, Archive of Novi Pazar, interviews with 2 ethnologists, 2 university professors, 6 local masters and civilians as to find all possible sources about traditional architecture in Novi Pazar. 


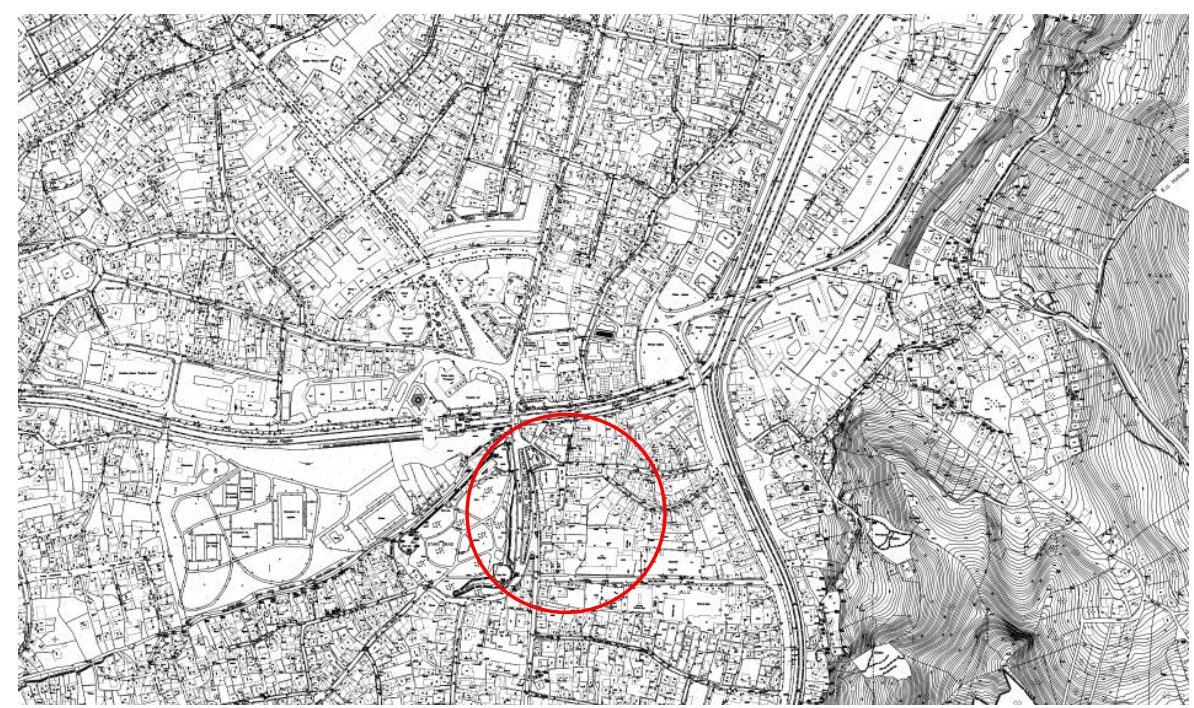

Figure 1: Site plan of Novi Pazar, 2012. (Source: Urban Planning Office of Novi Pazar.)

The next step was based on detailed technical observation to determine houses with different characteristics and high quality architectural features.

From 80 remained traditional houses in selection of 18 houses (according to the oral historic studies built in period from 1830 to 1920), construction techniques are examined in details such as masonry wall and timber frame techniques, mortars and plasters, floors and ceiling coverings, roof structure and indoor architectural elements.

All of these architectural features are documented in details by means of survey drawings, photos and interviews with the users. For 80 houses an inventory card is prepared for each one including photos and some general architectural information.

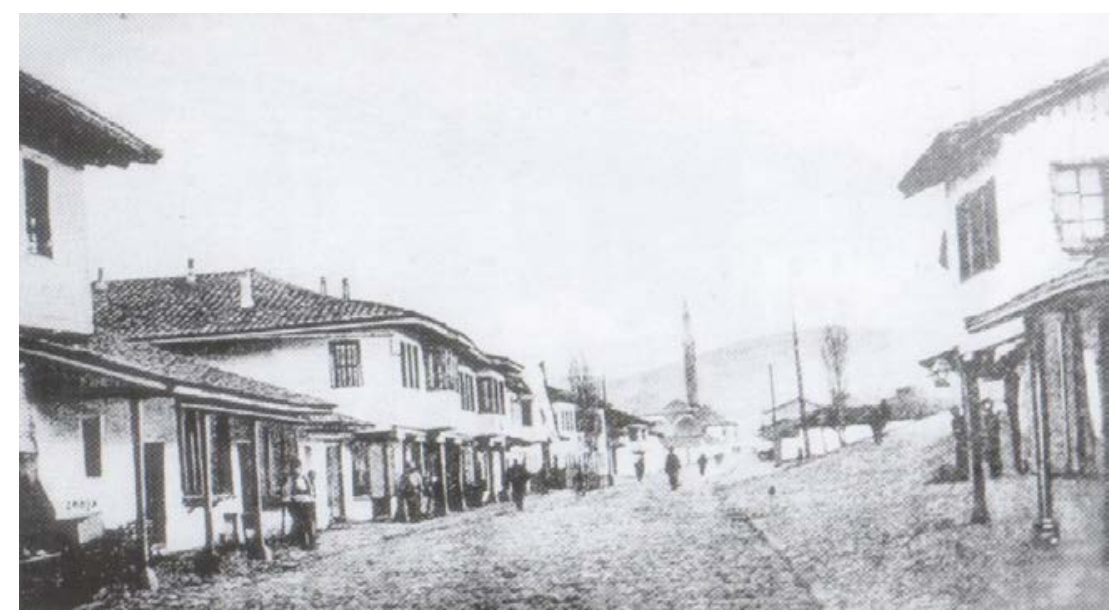

Figure 2: Stambol road in Novi Pazar, 1930. (Source: Archive Ras of Novi Pazar.) 


\section{MATERIALS AND CONSTRUCTION TECHNIQUES}

The basic construction elements and materials of Novi Pazar houses such as walls, floors, oriels, windows, doors, lamp windows, stairs and roofs are described in this part. The dimensions of the selected houses are 9.5-13.70 × 8.90-11.40 m. Traditional house in Novi Pazar usually has two stories separated according to their use.

The ground floor has entrance hall ("hajat"), kitchen, pantry ("izba", cold room connected to kitchen), one or two rooms and corridor that connects all these spaces. Because of the wall thickness, the ground floor is preferred during winter season. The first floor is designed with more attention. The central hall called "sofa" ends with the oriel ("divanhana") which is also carefully designed.

The most important room known as "alaturka" is planned and decorated for guests. All the rooms are multifunctional and used as living and bedroom in a day. Families with more members or those which are in better economic condition have kitchen on both floors.

\subsection{Walls}

Neither foundation depth nor used stone types are much known. The construction techniques of external load bearing walls can be classified depending on position due to the cardinal directions and depending on building period. Walls made with stone or adobe bricks (size $26 \times 14 \times 6 \mathrm{~cm}$ ) are usually located on the north and west sides of the house.

The thickness of the walls is less in the houses built after 1900. The used rubble ("sidraž") stones are obtained from the quarries in and near Novi Pazar. The stones at the corner of the load bearing walls are sculpted to form a right angle. The wooden runner beams (size $10 \times 10 \mathrm{~cm}$ or $10 \times 12 \mathrm{~cm}$ ) are made of oak or nut. They are tied to each other by transversally placing runner beams with a spacing of $60-80 \mathrm{~cm}$. The traditional mortar used for walls is made with soil, bran and straw.

The external load bearing walls seen in observed houses are cited below:

a) Stone base (20-30 cm high, 40-60 cm width) + adobe blocks walls (40 cm width with wooden runner beams repeating on $60-80 \mathrm{~cm}$ height on ground and first floor).

b) Stone base (40-150 cm high, 40-60 cm width) + masonry walls (20-30 cm width with wooden runner beams repeating very often and filled with stone or adobe blocks on ground and first floor) (Fig. 3).

c) Stone base + timber framed wall with adobe brick infill, stone or pieces of other materials as roof tiles with wooden runner beams repeating on $60-80 \mathrm{~cm}$ on ground floor (Fig. 4).

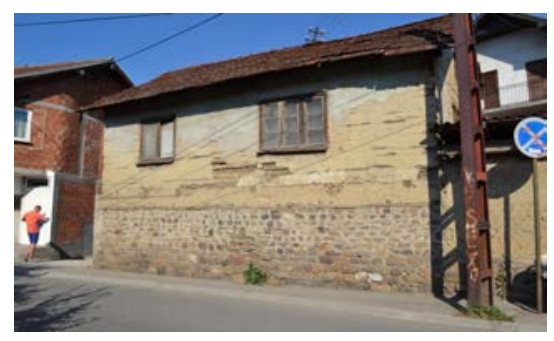

Figure 3: High stone base, often with runner beams, adobe blocks and small stones infill (type "b"). (Source: Ugljanin.)

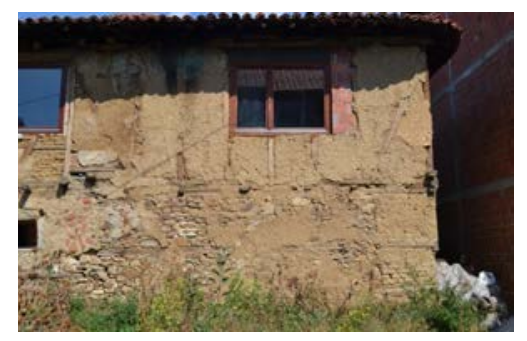

Figure 4: Timber framed wall with adobe brick infill, stone and roof tiles (type “c”). (Source: Ugljanin.) 
d) Stone base $(60-80 \mathrm{~cm}$ high $)+$ adobe blocks wall $(54-62 \mathrm{~cm}$ width with wooden runner beams repeating on $80 \mathrm{~cm}$ high on ground floor) + timber framed wall with adobe brick infill (30 $\mathrm{cm}$ width on first floor).

e) Stone base (30-50 cm high, $50 \mathrm{~cm}$ width) + timber framed wall with adobe brick infill (same width as base on the ground floor and $22 \mathrm{~cm}$ width on first floor).

The external thin walls are usually on south and east side of the house. They have many openings such as doors and windows. Their wooden construction (wooden pillars and beams) is filled with some materials such as soil, straw, pieces of roof tiles and similar. Their thickness is $16-20 \mathrm{~cm}$ at ground and first floor. The in general inner partition walls are formed by wooden pillars (size: $8 \times 8 \mathrm{~cm}$ or $10 \times 10 \mathrm{~cm}$ ) and have $16-20 \mathrm{~cm}$ thickness. The inner partition walls can be classified in 3 groups:

a) Wooden structure filled with adobe blocks (size $26 \times 14 \times 6 \mathrm{~cm}$ ).

b) Wooden structure filled with small stones or combination of different materials such as pieces of roof tiles and stone.

c) Wooden structure filled with wood laths from both sides.

\subsection{Floors}

The structure of floors is basically formed of wooden beams that carry the load and pillars that transfer it. The dimensions of the beams are usually $13 \times 15 \times 250-300 \mathrm{~cm}$ and placed with distance of $60-80 \mathrm{~cm}$. Wood used for beams are pine, spruce, oak or nut.

\subsubsection{Floor coverings}

Depending on the function of space stone, soil and wood is used for the floor coverings of Novi Pazar houses. At the ground floor kitchen and pantry ("izba", space with two masonry walls) are covered with rammed soil as to keep low temperature even during summer days so meat, cheese and vegetables can stay fresh.

The entrance hall ("hajat") is usually covered with local slate stones "siga" (Fig. 5) and rooms with timber planks. Width of timber planks changes from 13 to $45 \mathrm{~cm}$ where most common dimensions are $20-35 \mathrm{~cm}$.

The planks are usually timber dark pine so it is easy to walk on. There are examples of heat isolation between floors with soil in floor structure (Fig. 6).

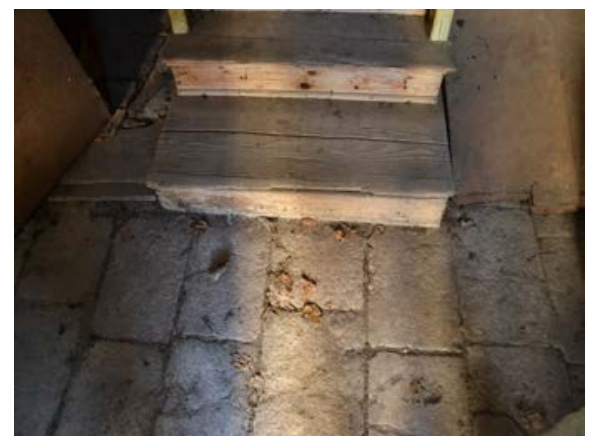

Figure 5: Entrance hall floor covering with local slate stone "siga". (Source: Ugljanin.)

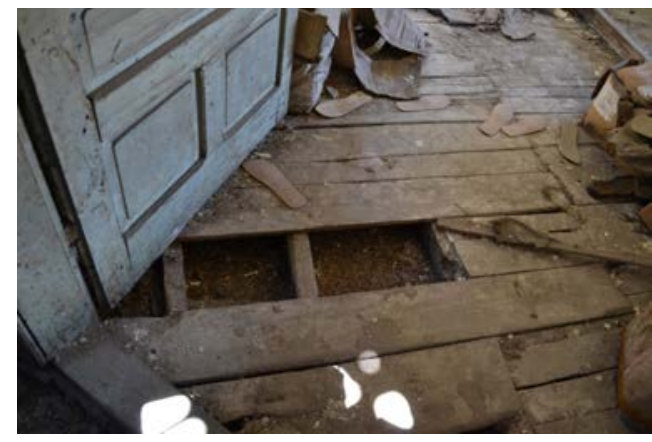

Figure 6: Soil as isolation under timber planks in floor. (Source: Ugljanin.) 


\subsection{Ceiling coverings}

The covering type used also depends on the function of the space. There are five ceiling covering types seen in Novi Pazar traditional houses:

a) Joint ceiling (“šašovci”): the most common covering technique seen in Novi Pazar houses rooms, halls and corridors. The main characteristic of "šašovci" is its constructive and decorative role at the same time. Timber beams are structure elements that have thin bed joint in the lower part of beam height so small wooden planks ( $1.5 \mathrm{~cm}$ thickness) could be placed between two beams. "Šašovci" boards are made from beech that is firstly smoothen than placed in each other so they all get linked to beams and each other (Figs 7 and 8). The most common dimensions of boards are $7-10 \times 60-80 \mathrm{~cm}$.

b) Geometric pattern ceiling ("baklava"): this technique is seen in 4 guest "alaturka" rooms. The wooden beams are covered by wooden boards and small wooden pieces fixed on boards form geometrical shapes such as quadrilateral, circle or polygon. The center of "baklava" is usually decorated with medallion.

c) Coffered ceiling ("tekne"): it is very rare but well known technique mostly seen at guest room ("alaturka") in qualified Novi Pazar houses. The center of the room is higher with polygon base wooden dome while the flat parts of the ceiling are neither "baklava" nor some other covering type (Fig. 9).

d) Plastered ceiling: the ceiling in small rooms on ground floor in houses from 1830 to 1870 (according to oral studies) is just plastered. The beams are covered by thin wooden laths and plastered. The traditional plaster (“čokmalter") consists of lime and ash. Ash is leaved until thicken so it can stand stable (sometimes salt is added at the end).

e) Visible wooden structure: this can be seen rarely in kitchens and pantry or corridors. The wooden beams are not covered by boards and are not plastered.

\subsection{Oriels}

The oriels in houses in Novi Pazar have symbolic meaning and have important part in typology of houses in this area. Most common position for oriels is center of the façade so it gives symmetric look and another is corner oriel where it takes place on two façades. As a part of culture, room for having coffee with guest should be oriented either to yard view or street.

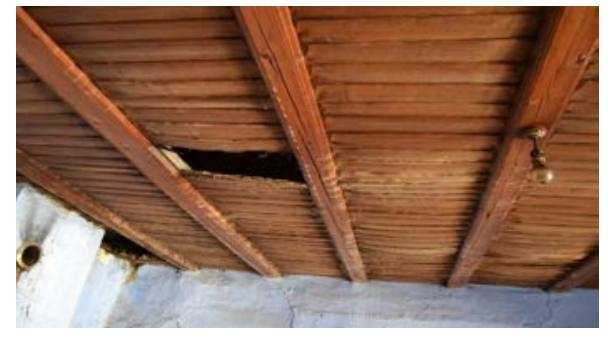

Figure 7: "Šašovci” ceiling covering (type "a"), picture. (Source: Ugljanin.)

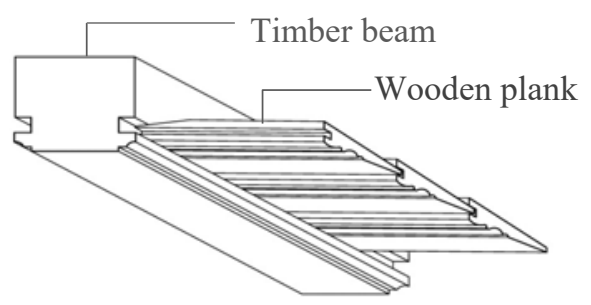

Figure 8: "Šašovci" ceiling covering (type "a") drawing. (Source: Ugljanin.) 


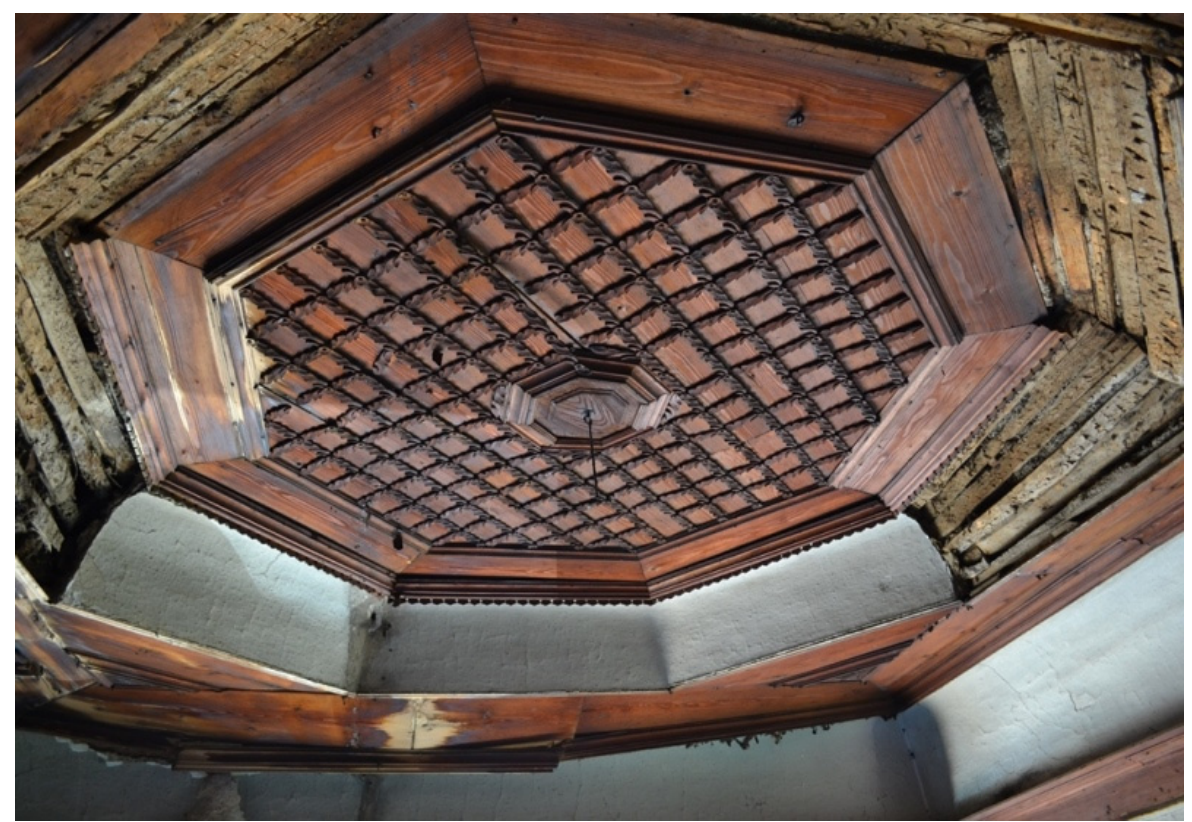

Figure 9: Coffered ceiling (type "c"). (Source: Ugljanin.)

This place in houses is usually specially decorated and characteristic with windows that enlighten the room. The oriels are constructed through extending the wooden beams $90-120 \mathrm{~cm}$ from the main load bearing walls. The load beams have sometimes "šašovci" joint detail.

The oriels walls are timber framed infill adobe brick. The façade is plastered the same like the rest except that it sometimes has wooden decoration which is mostly rhomb (diamond) shaped (Fig. 10).
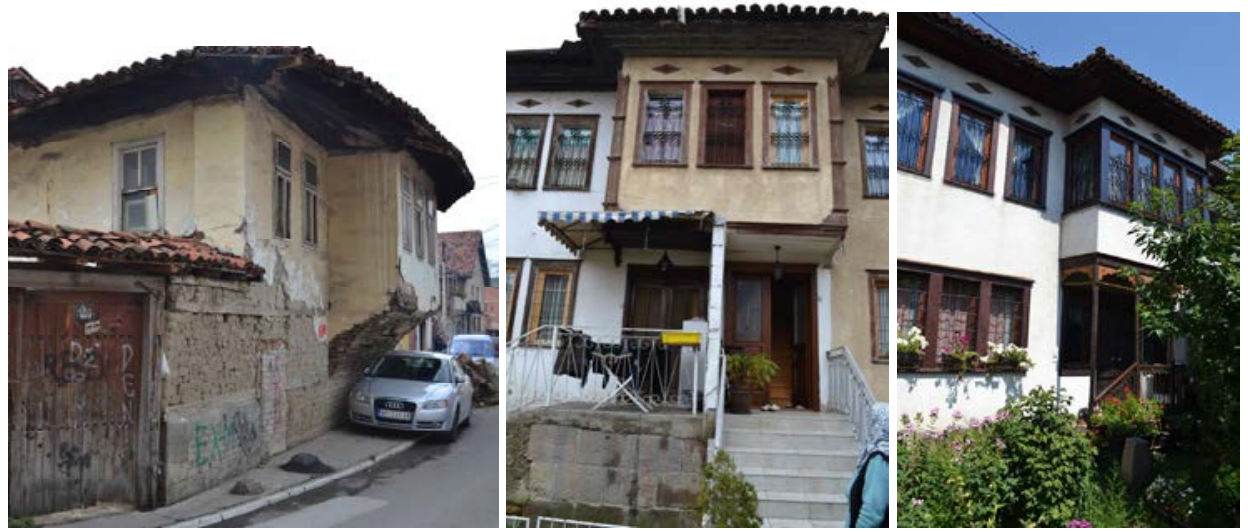

Figure 10: Oriels (Source: Ugljanin.)

WIT Transactions on The Built Environment, Vol 171, @ 2017 WIT Press www.witpress.com, ISSN 1746-4498 (on-line) 


\subsection{Windows}

The size of the service places windows on ground floors is approximately $40 \times 40-50 \times 50$ $\mathrm{cm}$ whereas the windows of the living spaces on any floor have a width of $60-80 \mathrm{~cm}$ and a height of 120-130 cm. Living space usually has many windows where all can be opened. Windows have security metal bars on both floors where bars on the upper floor have decorative role too. Houses from earlier years of the 19th century have wooden security bars ("toplije") formed through interlacing four wooden circular bars in the horizontal and four of those in the vertical direction. The interesting detail in Novi Pazar houses is that there are few examples of windows between two rooms that are usually between oriel and living room.

\subsubsection{Lamp window ("lambaluk")}

Specific detail of lightening in the house is small window that connect two spaces while lightening them. This "lambaluk" have windows on both sides of the wall so it can be opened when needed. The space for lamp has opening on the upper side of the wall that serves as chimney (Fig. 11).

\subsection{Doors}

All external and internal doors are made of pine. Ground floor entrance door is usually two leaf doors with width $120-140 \mathrm{~cm}$ and $195 \mathrm{~cm}$ height, whereas the size of one entrance door leaf is approximately $60-70 \times 195 \mathrm{~cm}$. The door leafs are constructed as batten door regardless of the use of space. The characteristic feature of the doors is iron door handles, knockers and other accessories with different designs and symbolic meanings (Fig. 12).

Interior doors are usually $90 \times 190 \mathrm{~cm}$ except some less used spaces with doors of $70 \times 195 \mathrm{~cm}$ with iron handles.

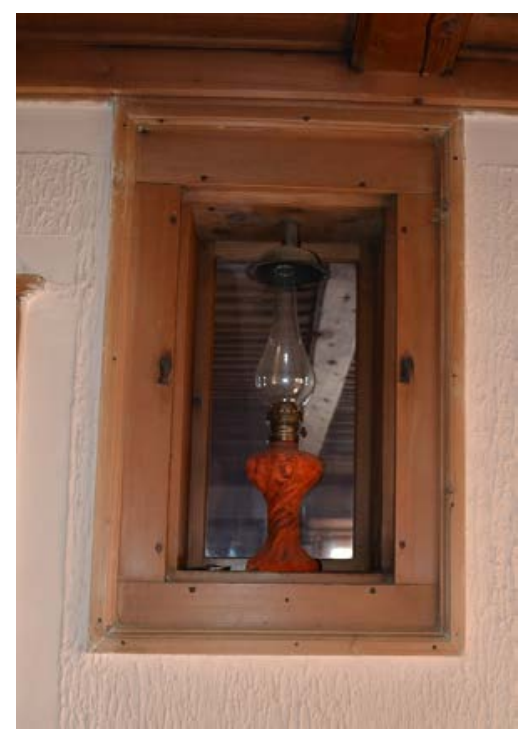

Figure 11: Lamp window. (Source: Ugljanin.)

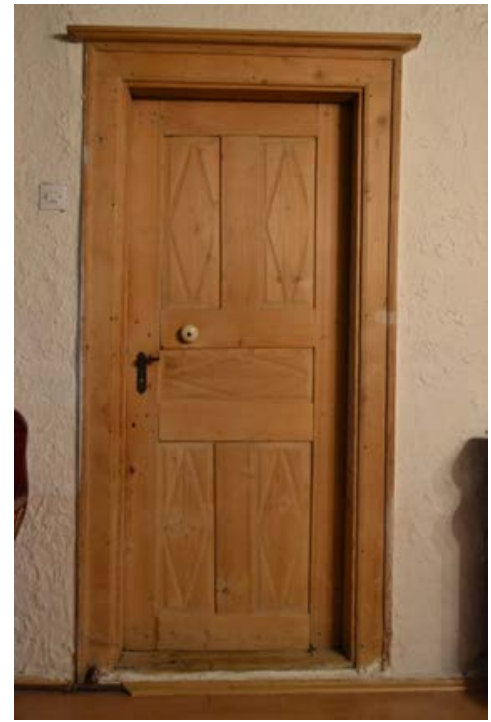

Figure 12: Internal door. (Source: Ugljanin.) 
Internal doors in mostly all traditional houses are decorated with rhombs on the both side and this decoration is sometimes seen on the entrance door too. Except rhombs there are few examples of other geometrical shape decorations.

\subsection{Stairs}

The floors of the houses are connected by wooden stairs with no ornamental finishing except the fence, which are located in the entrance hall "hajat".

The maximum thickness of wooden stairs is $3.5 \mathrm{~cm}$, the width is $30 \mathrm{~cm}$ and the length is $95 \mathrm{~cm}$. The stairs are into two wooden inner string boards (size: $10 \times 10 \mathrm{~cm}$ or $10 \times 15 \mathrm{~cm}$ ), applying a riser height of maximum $20 \mathrm{~cm}$.

Wooden trap-doors ("tahtapoš") of approximately $3 \mathrm{~cm}$ thickness, which close the stairwells, serve to ensure isolation and privacy between the floors (Fig. 13).

\subsection{Traditional oven}

Oven is built from stone and heat resistant bricks. Length of ovens is between 130-150 cm, width 60-90 cm, inner depth 40-70 cm and inner height $70 \mathrm{~cm}$ (Fig. 14).

\subsection{Roof}

All roof elements are wooden with dimensions that changing from roof to roof. The wood types used are spruce, beech, oak and pine because of their strength. The wooden rafters placed in small distance with many supporting hangers have circular or quadratic shape. Angle of pitched roof inclination is $25 \%$ due to climate.

The roof is constructed without placing sarking boards under the tiles. The roof tiles are specific for Ottoman houses in general, not only in Novi Pazar, and are called "ćeremida".

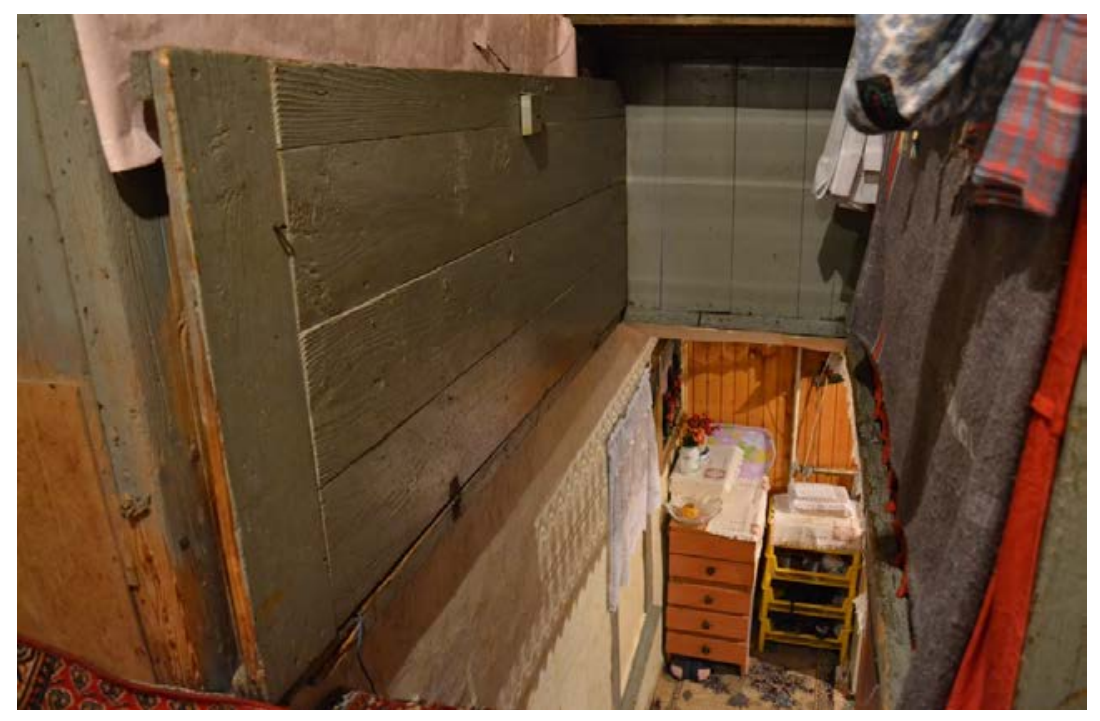

Figure 13: Wooden trap-doors (“tahtapoš”). (Source: Ugljanin.) 


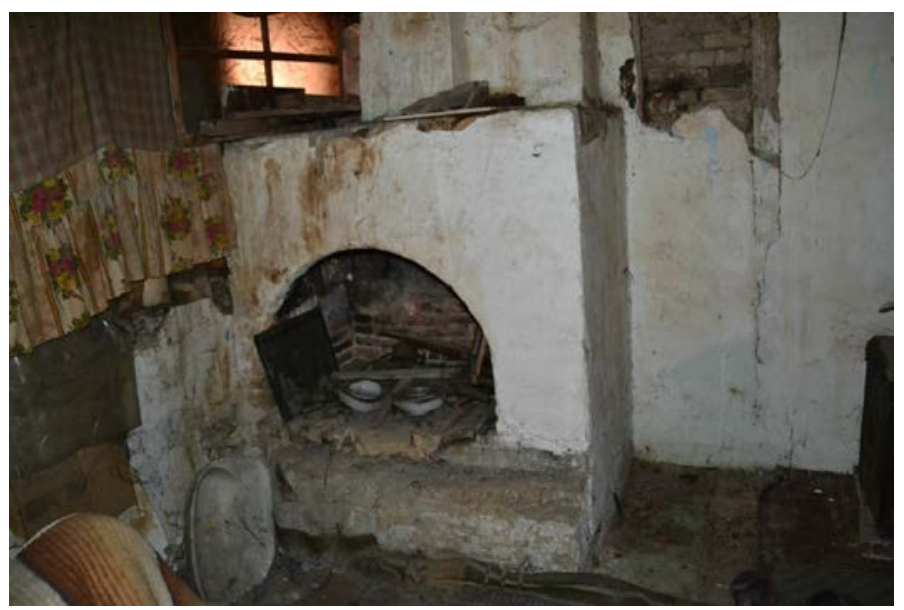

Figure 14: Traditional oven. (Source: Ugljanin.)

\subsection{Eaves}

In traditional houses, eaves are $40 \mathrm{~cm}$ long and there are 2 types:

a) Eaves without coverings: Basic type of eave where roof structure rafters are visible in the way they are used. Rafters have sometimes profiled shaped with axe (Fig. 15).

b) Eaves with coverings: Eaves of the houses that date back to the early years of 20th century have timber covering so structure is not visible anymore. Timber covering is sometimes formed of small planks fixed to the wooden rafters (Fig. 16).

\section{CONCLUSIONS}

The aim of this study is to document the architectural features of Novi Pazar timber houses and also to raise awareness in conservation of traditional civil architecture. It is determined that Novi Pazar houses carry general characteristics of traditional Ottoman houses built in Anatolia but also have some specifics architectural features such as joint ceiling coverings ("šašovci") and lamp window. During the research, it is observed that there are several

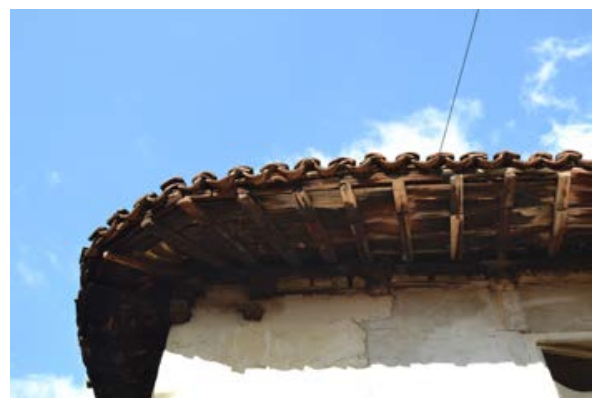

Figure 15: Timber covering formed of planks joined together. (Source: Ugljanin.)

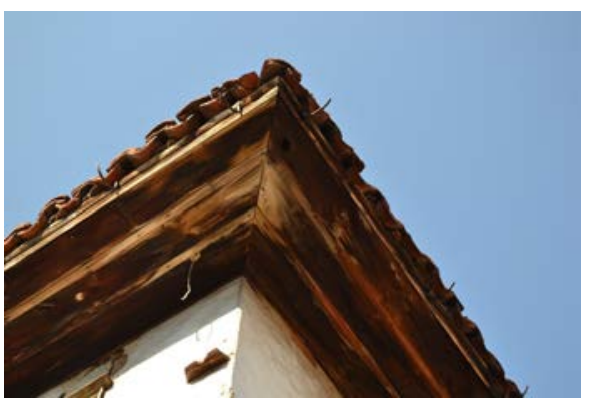

Figure 16: Rafters shaped with axe (Source: Ugljanin.) 
conservation problems that frequently repeat and cause damage continuously to Novi Pazar houses. Some of these problems are cited below:

a) Bad economic situation of families and lack of interest in restoration of Republic of Serbia and Ministry of Culture.

b) Destruction of traditional houses for building apartments (two unique examples are destructed during this research and just a few of all destructed houses are documented with few photos).

c) Unqualified interventions and repairs of users.

d) Lack of local masters with knowledge about traditional building techniques.

Also, there is lack of traditional material production such as roof tiles and adobe bricks. To identify the local materials and construction techniques in detail would make a contribution to future conservation and restoration works. Therefore, for the transfer of the traditional building knowledge it is proposed making plans for educating new local masters and architects through internship programs, workshops, seminaries or conferences. It will be possible than to apply with restoration projects to many national or international institutions for financial support.

In spite of great value that traditional Novi Pazar civil architecture has, all possible effort will be given by the researcher as to accelerate the process of preservation works.

\section{NOTES}

This study is based on the Master of Sciences thesis of Samra Ugljanin who is a student at Yildız Technical University, Faculty of Architecture, Unit of Architectural Conservation. Aynur Çiftçi is the advisor of this thesis. All photographs were taken in 2015 and 2016 by Samra Ugljanin and were part of the documentation that was completed in their Master's thesis. The local terms used in the text are stated in parenthesis and quotation marks (“....").

\section{ACKNOWLEDGEMENTS}

I would like to express my sincere thanks to Muradija Kahrović Jerebičanin ethnologist from Novi Pazar, local masters for explaining construction techniques, Archive Ras of Novi Pazar, Museum Ras of Novi Pazar and Novi Pazar people for their support and hospitality.

\section{REFERENCES}

[1] Kahrović, J.M., Novi Pazar u Vaktu i Zemanu, Novi Pazar, 2014.

[2] Muşoviç, E., Yeni Pazar Nüfusunun Etnik Oluşumu ve Etnik Yapısı, Antalya, 2004.

[3] Krunić, J., Kuća i Varoši u Oblasti Stare Raške, Beograd, 1994. 